\title{
Comparative Evaluation of a Seed Planter, the Modified Version and Local (Hand) Seed Planting Method
}

\author{
Adedipe J.O ${ }^{1}$, Ajiboye O.O ${ }^{2}$, Olatunji B.T ${ }^{3}$, Owoloja A.O ${ }^{4}$, Afolabi R.T ${ }^{5}$, Ekaun A.A ${ }^{6}$, Adedipe D. \\ 1,2,3,4,5,6,7 Forestry Research Institute of Nigeria
}

\begin{abstract}
This study evaluated the performance of a seed planter against the modified version, and hand planting method. A performance test was carried out on the two planters and hand method on a piece of land of known dimension over a period of time. Performance was evaluated using five (5) different parameters; sowing rate, area covered, throughput capacity, efficiency and level of uniformity. Sowing rate showed that hand method had the lowest sowing rate of 1 seed per sec, while the modified planter had the highest sowing rate of 5 seeds per sec. The modified planter had the highest for area covered at $91.5 \mathrm{~m}^{2}$, while the existing planter performed second best at $73.5 \mathrm{~m}^{2}$. Throughput capacity was highest for the modified planter at $292.8 \mathrm{~kg} / \mathrm{hr}$ and lowest for hand planting method at $29.3 \mathrm{~kg} / \mathrm{hr}$. Efficiency result showed that hand method was better than the existing method at an efficiency value of $94 \%$ against $89 \%$ for existing planter; the modified planter performed best at $97 \%$ efficiency value, while uniformity result showed that the modified planter was the best along the row and column arrangement at $97 \%$ for both, while hand method had the lowest for both cases at $85 \%$ and $88 \%$ respectively. This study showed that the modified planter performed better than the two others in all the parameters assessed.
\end{abstract}

KEYWORDS: Planter, existing, modified, hand, performance

\section{INTRODUCTION}

Planting is the actual placement of seed or vegetative material into the soil. Planting could be by seed or planting of vegetative materials, some crops are propagated solely through seed examples are maize, rice, cowpea, millet, pepper, vegetable and so on. Seed planter is a farm implement that is used to plant seed. It enables easy and adequate spacing of the seed. It can be used for planting in a single row as well as multiple rows. It reduces the working effort of the farmer and enables them to cover larger percent of the farmland within a short duration (Srigiri D. 2016). The seed planter could be designed with different diameter according to the diameter of the seed that the machine will be used to plant. Under intensive cropping, timeless of operation is one of the most important factors which can only be achieved if the appropriate use of agricultural machine is adopted. Manual method of seed planting results in low seed placement, spacing efficiencies and serious backache for the farmer which limits the size of field that can be planted. To achieve the best performance from a seed planter, the above limits are to be optimized by proper design and selection of the component required on the machine to suit the need of crops (Ramesh and. Girishkumar 2014).

In the past, various type of design has been developed with different design approaches which have their advantage and disadvantage and also limitation. Adisa and Braid (2012) designed and constructed a manually operated flute planter/fertilizer distributor which was found to be $94 \%$ efficient in seed spacing but could not be used on the ridged seed bed and requires quite some effort and time to change seed drill size.

Also Braide and Njidda (1989) developed a combined jab planter which was found to be $73.4 \%$ efficient and was three times faster than manual planting with hoe and cutlass. Braide and Ahmadu 1990 developed a trans planter for some selected guinea savannah of Nigeria which has $0.19 \mathrm{ha} / \mathrm{h}$ field capacity and $20 \%$ field efficiency. All of the above designs were reported to have got quite promising results.

\section{STATEMENT OF THE PROBLEM}

This study evaluated the original planter against the modified version against local planting method by planting maize using the respective planter/planting method. Farmers usually use a lot of energy in planting of seeds; they make use of traditional method (Hoe and Cutlass) which took a longer time to cover a large surface of land. This therefore necessitated the development of a row seed planter and a modified version of the same. The modified version was an upgrade of the original design. This was to correct some faults, defects and to improve the overall productivity level of the latter.

\section{METHODOLOGY}

An existing design of seed planter and its modified version were critically assessed before selection for this study; they 
were taken to the field for performance test and evaluated. The limitations on the former and the correction on the latter were noted.

\section{MATERIAL SELECTION}

The following factors were considered during the material selection; the durability of the planters, the overall cost of each planter, the convenience of production, ease of accessibility to local and subsistence farmers, the routine maintenance of the planters

\section{DESCRIPTION OF THE SEED PLANTERS}

The components of the seed planters machine includes: a main frame, a handle, seed hopper, seed metering device, adjustable furrow opener, adjustable furrow coverer, drive wheel, seed tube and a bearing selection; most of these were fabricated from metallic material. The two planters considered have several similar features, while some of the features on the modified planter are upgraded versions of those on the existing planters: these features include;

\section{i. Main frame}

The main frame is the skeletal structure of the seed planter on which all other component are mounted.

\section{ii. Adjustable handle}

The adjustable handle of the seed planter was designed to be adjusted for the different heights of individuals thereby reducing drudgery. The handles help the operator to push the planter while n operation.

\section{iii. Seed hopper}

The seed hopper as the name implies is a device in which the seeds to be planted are kept before they are gradually released into the furrowed tunnel. The hopper has the shape of a frustum of a pyramid truncated at the top.

\section{iv. Seed metering device}

Metering device is the heart of sowing machine and its function is to distribute seed uniformly at the desired application rates. In planters, it also controls seed spacing in a row. A seed planter may be required to drop the seed at rate varying across wide range. Proper design of the metering device is an essential element for satisfactory performance of the seed planter. The size and the number of cells on the roller depend on the size of seed and at a desired seed rate. The metering device or roller lifts the seed in the cells and drops these into the seed tube which is conveyed to the open furrow, for varying the seed rate and sowing different seeds.

\section{v. Adjustable furrow opener}

The design of furrow opener of seed planters varies to suit the soil conditions of particular region. Most seed planters are provided with pointed tool to form a narrow slit in the soil for seed deposition. The adjustable furrow opener permits planting at different variety depths. The type used for this work is the pointed bar type.

\section{Adjustable furrow cover}

vi. The furrow cover was also design to be adjustable. The type used for this design is the

shoe type furrow cover. It was designed to allow for proper covering and compaction of the soil over the seeds in the furrows. The material used for the design was made of mild steel sheet.

\section{vii. Seed tube}

This component is the channel through which the seeds are conveyed to the furrow.

Table 1 below highlights some notable differences between the existing seed planter and the modified planter:

Table 1: Differences between the existing seed planter and the modified planter

\begin{tabular}{|l|l|}
\hline Existing planter & Modified planter \\
\hline Hopper has no lid & Hopper has a lid cover for raining days \\
\hline Metering device was designed for maize planting & Metering device can be replaced to suit the planting of different seeds \\
\hline Steel materials were used for fabrication & $\begin{array}{l}\text { Steel were replaced with aluminum materials to reduce weight and } \\
\text { prevent corrosion }\end{array}$ \\
\hline Wheels were made from steel & Steel wheels were replaced with pneumatic tyres \\
\hline Metering device was made from steel & Metering device was made from wood \\
\hline
\end{tabular}

The plates 1, 2 and 3 below shows the physical features of the two (2) planters, i.e the exixsting planter and the modified one;

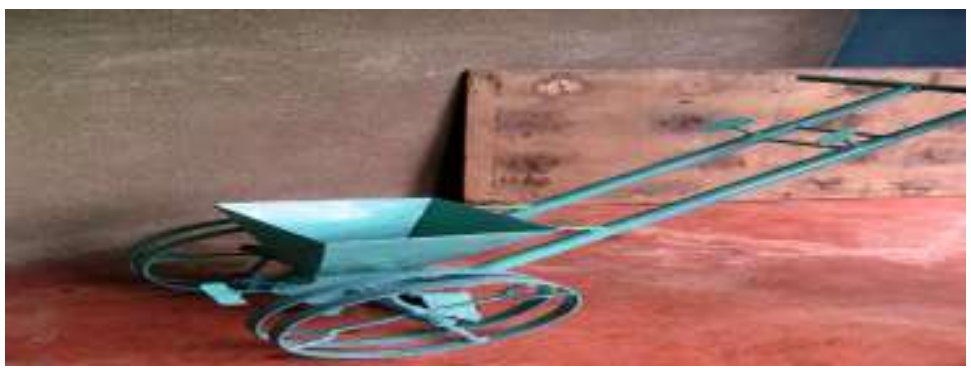

Complete assembly of planter

Plate 1: Existing planter 


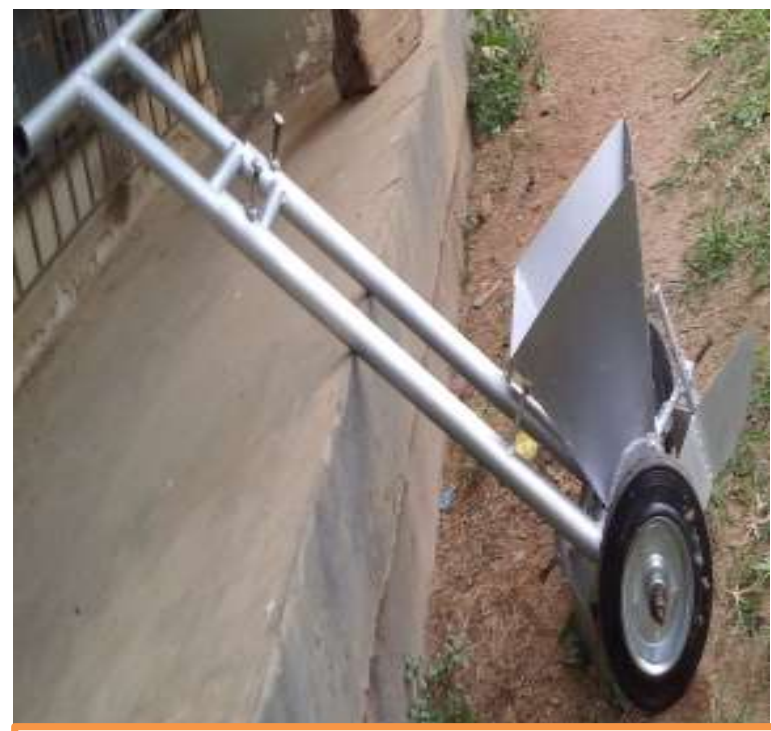

Plate 2: Front view of the modified planter

\section{EVALUATION PARAMETERS}

The following parameters were used in evaluating the already existing seed planter;

1. Sowing rate (seed per time)... this is the ratio of seed sown to the time in seconds

That is, Sowing rate $=$ Number of seed sown

\section{Time}

2. Area covered ... this is the total surface area covered over a given period of time, and measured in meter squared $\left(\mathrm{m}^{2}\right)$

Mathematically $A=l \times b$

Where

$$
\begin{aligned}
& \text { A ... Area }\left(m^{2}\right) \\
& L \ldots \text { Length }(m) \\
& B \quad \ldots \text { breath }(m)
\end{aligned}
$$

3. Throughput capacity $(\mathrm{kg} / \mathrm{hr})$... this is the ratio of seeds planted to the time used and measured in $\mathrm{kg} / \mathrm{hr}$

Mathematically $V=d / t$

Where

$$
\begin{aligned}
& \text { V ........working speed }(\mathrm{m} / \mathrm{s}) \\
& \text { D ..........distance covered }(\mathrm{m}) \\
& \mathrm{t} \text {........time (s) }
\end{aligned}
$$

4. Efficiency ... The efficiency of the machine was calculated using the equation below:

$$
\text { Efficiency }=\left[\frac{\{p 1-p 2\}}{p 1}\right] \times 100
$$

\section{RESUT AND DISCUSSION}

Table 2: Assessed parameters for the three planting methods

\begin{tabular}{|c|c|c|c|c|c|c|}
\hline S/N & $\begin{array}{c}\text { Sowing rate } \\
\text { (seed per sec) }\end{array}$ & $\begin{array}{c}\text { Area covered } \\
\left(\mathrm{m}^{2}\right)\end{array}$ & $\begin{array}{c}\text { Throughput capacity } \\
(\mathrm{kg} / \mathrm{hr})\end{array}$ & $\begin{array}{c}\text { Efficiency } \\
(\%)\end{array}$ & \multicolumn{2}{|c|}{ Uniformity (\%) } \\
\cline { 6 - 8 } & 1 & 9.2 & 29.3 & 94 & 85 & 88 \\
\hline Hand & 1 & 73.5 & 235.2 & 89 & 94 & 94 \\
\hline Existing & 4 & 91.5 & 292.8 & 97 & 97 & 97 \\
\hline Modified & 5 & &
\end{tabular}

Where planted

p1 ----- number of furrow well planted

p2 ----- number of furrows not well

5. Percentage uniformity $(\mathrm{m})$... This is a measure of the consistency of the distance apart between furrows along both rows and columns.

Mathematically

Percentage uniformity (row) $=$ number of furrows $>$ or $<75 \mathrm{~cm}$ apart $x 100$ Total number of furrows

Percentage uniformity (column) $=$ number of furrows $>$ or $<25 \mathrm{~cm}$ apart $x 100$ Total number of furrows

\section{Performance test}

A portion of land of known dimension was selected, maize was purchased from the market; $30 \mathrm{~kg}$ of grains were selected and divided into three equal parts. Planting of maize was done by hand, the use of an existing planter and the modified seed planter. Planting was done on a rainy day, on a dry day, on a well cultivated soil and on an uncultivated soil. The time taken for each method was noted and other assessment parameters were measured and recorded. The three (3) methods were compared and deductions were drawn. 


\section{Discussion}

Table 2 above summarizes the result of the parameters assessed in evaluating the three (3) maize planting methods. Sowing rate shows that hand method had the lowest sowing rate of 1 seed per sec, while the modified planter had the highest sowing rate of 5 seeds per sec. The modified planter had the highest for area covered at $91.5 \mathrm{~m}^{2}$, while the existing planter performed second best at $73.5 \mathrm{~m}^{2}$. Throughput capacity was highest for the modified planter at $292.8 \mathrm{~kg} / \mathrm{hr}$ and lowest for hand planting method at $29.3 \mathrm{~kg} / \mathrm{hr}$. Efficiency result showed that hand method was better than the existing method at an efficiency value of $94 \%$ against $89 \%$ for existing planter; the modified planter performed best at $97 \%$ efficiency value. Lastly, uniformity result showed that the modified planter was the best along the row and column arrangement at $97 \%$ for both, while hand method had the lowest for both cases at $85 \%$ and $88 \%$ respectively

Figure 1 below gives a detailed summary detail of table 2 in a graphical mode.

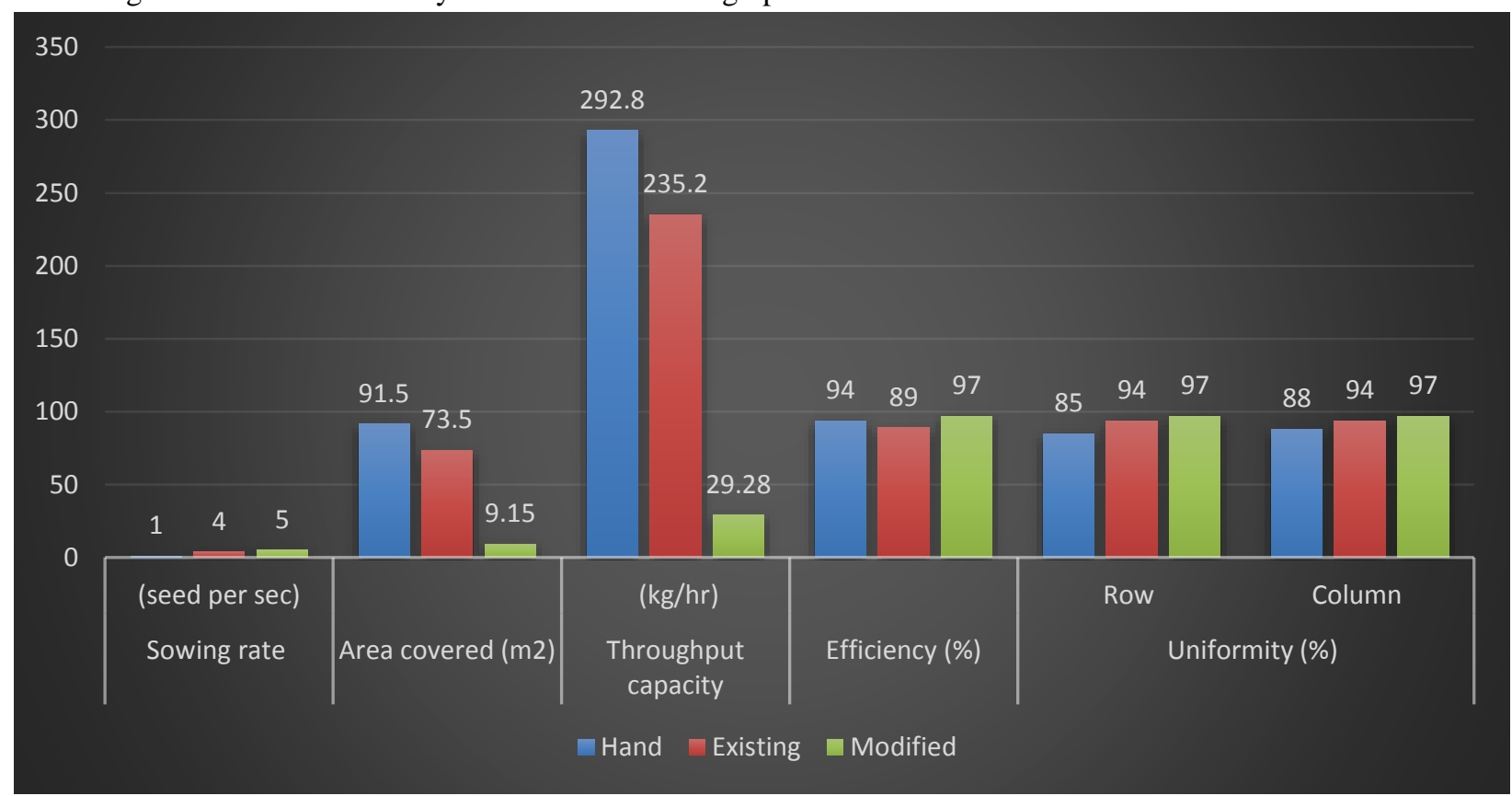

Figure 1: Graph of all assessed parameters for the three (3) planters

\section{CONCLUSION}

The three planters for this study were each used to carry out a performance test on a piece of land of known dimension over a period of time; performance was evaluated using five (5) different parameters. Sowing rate shows that hand method had the lowest sowing rate, while the modified planter had the highest sowing rate. The modified planter had the highest for area covered, while the existing planter performed second best. Throughput capacity was highest for the modified planter and lowest for hand planting method. Efficiency result showed that hand method was better than the existing method. Lastly, uniformity result showed that the modified planter was the best along the row and column arrangement at $97 \%$ while hand method had the lowest for both cases. This study showed that the modified planter performed far better than the two others in all the parameters assessed.

\section{REFRENCE}

1. Adisa A.F and Braide F.G, 2012. Design and Development of Template row planter. Transitional Journal of Science and Technology. Vol 2, No 7.
2. Braide F.G and S.M Njidda 1989. Design and construction combined jab planter. Proceedings of Nigerian Society of Agricultural Engineers (13)

3. Braide F.G and Ahmadu 1990. Developed a Tranplanter for some selected crops in the guinea savannah region of Nigeria. Proceediung of the InternationalAgricultural Engineering Conference and Exhibition, Thailand.

4. Srigiri D. (2016) Development of Single Row Manually Operated Multi Crop Planter.International Journal of Agriculture Sciences, Volume 8, Issue 30, pp. 1632-1634.

5. Ramesh, D., H.P. Girishkumar (2014) Agriculture Seed Sowing Equipment: A Review. International Journal of Science, Engineering and Technology Research (IJSETR), Volume 3, Issue 7 pp. 19871992. 